\title{
MINING
}

UDC 622.243

M. T. Biletsky ${ }^{1}$, Cand. Sc. (Tech.), Assoc. Prof., orcid.org/0000-0002-4947-5686, A. A. Kozhevnykov ${ }^{2}$, Dr. Sc. (Tech.), Prof., orcid.org/0000-0002-6876-4168,

B. T. Ratov ${ }^{1}$, Dr. Sc. (Tech.), Prof., orcid.org/0000-0003-4707-3322,

V. L. Khomenko ${ }^{2}$, Cand. Sc. (Tech.), Assoc. Prof., orcid.org/0000-0002-3607-5106
DOI: $10.29202 /$ nvngu/2019-1/22

1 - Caspian Public University, Almaty, the Republic of Kazakhstan, e-mail: biletskymarc@yandex.ru; ratov69@mail.ru 2 - Dnipro University of Technology, Dnipro, Ukraine, e-mail: aak2@ua.fm; inteldriller@gmail.com

\section{DEPENDENCE OF THE DRILLING SPEED ON THE FRICTIONAL FORCES ON THE CUTTERS OF THE ROCK-CUTTING TOOL}

Purpose. Forecasting the deepening in one revolution and the mechanical drilling speed, taking into account the decrease in the actual axial load due to the action of the frictional force.

Methodology. The analytical model of the vertical and horizontal displacements of the indenter along the surface of the rock has been improved. It is detailed with reference to drilling of boreholes with crowns of cutting type taking into account the reduced actual axial load, acting on the cutter, on rocks with physical and mechanical properties.

Findings. It is established that during the drilling, the true axial load is less than the nominal load due to the frictional force arising on the front of the tool. The one-turn and the mechanical drilling speed are predicted taking into account the decrease in the actual axial load due to the action of the vertical friction force. It has been revealed that as the width of the tool is reduced, the axial load losses increase due to friction forces, and the deepening per rotation and the drilling speed decrease more intensively.

Originality. For the first time, the influence of the frictional force, which appears on the front of the tool of the rock cutting tool on the true axial load, the depression in one turn and the mechanical drilling speed, is shown. New analytical dependencies are proposed that allow one to predict the depth per one revolution and the mechanical drilling speed taking into account the design of the rock cutting tool and the geological and technical conditions of drilling.

Practical value. The developed model of the interaction of cutting allows predicting the results of the application of various designs and technologies for the development of a rock-sensing tool more reliably, as well as choosing rational technologies for their application to achieve maximum technical and economic indicators.

Keywords: drilling of wells, destruction of rocks, rock cutting tool, carbide crown, perforation in one turn, mechanical drilling speed

Introduction. The appearance of the first designs of carbide crowns is usually associated with the German inventor Hugo Lohmann, who from 1913-1914, invented a number of hard alloys. The conducted patent studies allowed, however, stating that the first patented carbide crown is the design described in German patent DE335805, which was issued by Alfred Stapf and Hans Hundrieser. The patent was claimed on 26.03.1920, it was issued on 14.04.1921 [1].

Since then, hard alloys have found a very wide application in drilling [2], and carbide bits and became the main rock-breaking tool for core drilling. However, at present the volume of hard-alloy drilling is constantly decreasing. They are replaced by shells with removable core-holders, equipped with diamond crowns, as well as

(C) Biletsky M. T., Kozhevnykov A. A., Ratov B. T., Khomenko V. L., 2019 crowns equipped with diamond-carbide plates (PDC). According to the principles of their work, crowns equipped with PDC are very close to carbide-tipped crowns and have common design principles. These crowns destroy the rock by cutting, in contrast to diamond crowns, where the abrasion process prevails at the contact of the diamond-rock.

The theory of interaction between a carbide tip or a crown equipped with an PDC and rock is fundamental for the improvement of the rock-destroying tools and the technology of their application. The study and improvement of this theory is necessary for:

- selecting ways for further research;

- determining the level of development of technology and the actual results achieved;

- identifying the shortcomings of existing crown designs and drilling technology; 
- developing new design solutions for the rock-cutting tool;

- forecasting the results of the application of various designs and technologies for working out a rock-sensing tool;

- choosing a rational technology for their application to achieve one or more of the following objectives:

- minimization of the cost of one running meter of the well;

- maximization of the mechanical or voyage drilling speed;

- maximization of penetration to the crown;

- achieving special goals (to increase the yield of the core, to deviate the well from the original direction, effective drill in the interval of geological complications, and others).

The last two tasks are closely interrelated. Precisely predicting the results of the application of various designs and technologies allows the shortest possible way to achieve maximum technical and economic indicators.

In core drilling with carbide and CRM-equipped crowns, the length of the voyage is short and much smaller than the penetration of the rock-cutting tool. This is an important difference from drilling chisels, where, as a rule, they tend to achieve a flight length equal to the drift per bit. The cost of carrying out the lifting operations is much higher than the cost of the carbide crown and increases with depth. Therefore, as a criterion for optimizing the process when drilling with carbide and DCTP-equipped crowns, the maximum of the mechanical drilling speed is adopted. Thus, the prediction of the mechanical drilling speed is an important and urgent task in the study of the process of rock fracture by cutting crowns.

Analysis of recent research and publications. To date, a huge number of works devoted to the design and development of technology for the use of carbide crowns have been published. Great contribution to the solution of this problem was made by: G. V. Artsimovich, D. N. Bashkatov, V.C. Vladislavlev, S.A. Volkov, L. K. Gorshkov, B. I. Vozdvizhenskyi, L. G. Grabchak, V. G. Kardysh, E.A. Kozlovskyi, N. I. Kulichikhin, B. B. Kudriashov, A. I. Osetskyi, A. N. Popov, V. M. Rebrik, A. I. Spivakov, S.S.Sulakshin, N. V. Soloviev, B.C. Fedorov, F. A. Shamshev, L. A. Schreiner, P. M. Eigeles, E. F. Epstein and many others.

At present, two main theoretical models of rock destruction in the process of drilling hard-alloyed and equipped with DCTP crowns and chisels have been distributed.

The first model considers drilling as a combination of two successive processes:

- introduction of the fixed tool of the rock-cutting tool (RCT) into rock face;

- propagation of the fracture zone from the penetration well over the whole face due to the rotation of the RCT and removal of the rock layer, the thickness equal to the penetration depth.

Thus, in work [3], the process of rock destruction is considered when indenting pyramidal and wedgeshaped indenters.
In work [4] the process of destruction of the rock by roller cone bits is analyzed with the indenter ball indentation, which simulates the process of elastic-plastic deformation of the rock by separate cutters of the drilling tool.

Also in the static state, the process of interaction of a roller bit with a face rock is considered, at the moment when each roller is supported by a flat face with a single tooth in the work [5].

With such an influence, fatigue destruction of rocks exerts a considerable influence. The susceptibility of rocks to the alternating loads shows by how many times the pressure at the point of contact between the teeth of the bit and rock (in comparison with the die hardness) can be reduced when designing the axial load on the bit [6].

The spreading over the well face process is considered an auxiliary one, $70-80 \%$ of its energy expenditure being ascribed to the cutter's friction against the well face.

Our opinion is that such a model can prove to be adequate on occasions, when in use is a drilling mode, consisting prevalently of imbeddings. It is the case with drilling with cone rock bits. Their cones in the course of rolling make their teeth alternatively plunge into closely situated sectors of the well face.

So, with roller drilling, the cutter's tooth, in the course of its rolling along the face, comes in contact with the rock, penetrates into it at a certain depth and leaves the contact, giving way to another tooth that hits the neighboring area.

The similar situation takes place at rotary-percussion drilling, where rock destruction is performed at the expense of impacts of cutters, while rotation only serves to uniformly distribute the impacts against a well face.

It should also be pointed out, that the theory of the cutter rock imbedding is developed mostly with relation to friable and elastoplastic crystalline rocks. In relation to ductile and porous formations (clays, loams, sandy clays and others) the theory is not so well elaborated.

Meanwhile, as the depth of the wells increases, under the influence of the rock pressure of the overlying rocks, as well as the hydrostatic and hydrodynamic pressures of the drilling fluid, the elastoplastic rocks acquire the properties of plastic rocks. In work [6] it is considered how the mechanism of destruction of rocks changes with increasing depth.

It is shown in [7] that the coefficient of compaction of the rock, $\lambda$, in connection with the increase in the depth of the well in the presence of drilling mud in the borehole, is expressed by the dependence

$$
\lambda=1+\frac{\gamma_{p} H_{0}}{10 \delta_{p}},
$$

where $\gamma_{p}$ is the density of flushing liquid, $\mathrm{kg} / \mathrm{m}^{3} ; H_{0}$ is borehole depth, $\mathrm{m} ; \delta_{p}$ is ultimate strength of the rock under compression, $\mathrm{Pa}$.

For the destruction of the rock by cutting, when the rock layer is removed by the moving cutter along the face "horizontally", this model is not adequate.

This model does not explain why a cutter, embedded in the rock, after the beginning of the "horizontal" dis- 
placement, continues its implementation, and does not retain the depth reached by indentation by the action of a static load. And the introduction in the course of the "horizontal" movement (to be precise, moving along an inclined spiral trajectory) constitutes the essence of rock destruction by cutting during rotary drilling.

The second model represents drilling as a combined process of horizontal and vertical movements of the indenter.

The simplest similar theoretical models of rock destruction are constructed with multiple assumptions and simplifications, the main ones being the following: cutting is considered as a two-dimensional process, while it is believed that there is no interaction between neighboring cuts (blocked cutting by a single cutter), possible inclusions and/or violations in the rock are ignored [8].

A mathematical model of the problem of the introduction of a wedge in a rock is constructed in [9], in which a plane deformation of a half-space is analyzed under the action of an extended asymmetric wedge in the cross section.

Often, when designing structures to increase the efficiency of the main incisors, their output over the end of the crown is made to a different size, while a stepshaped slaughter is obtained [10].

An important design parameter is also the inclination angle of the tool. Thus, in work [11], the influence of the PDC inclination angle on the wear resistance and loading of the drill bit was studied. Using the method of calculating the geometrical parameters of the drill cutters and the corresponding computer program, the working angular parameters of the drill cutter reinforced by the PDC are determined.

In [12], during the analysis of rock fracture while drilling with PDC bit cutters, the geometrical dependences of the normal cutting force and its components on the front cutting angle and the parameters of the area drilled by the cutter were obtained. Formulas are obtained for the dependence of the pressing force of the tool on the axial and tangential components of forces on the constant front cutting angle.

Unsolved aspects of the problem. In the above and other studies on the study of rock destruction by cutting, much attention is paid to predicting the depth of the cutter in one turn and the mechanical drilling speed. However, the examined and other models do not take into account the influence of the tool's frictional force on the rock on the reduction of the actual axial load acting on the cutter and the resulting decrease in the recess per revolution and the mechanical speed.

The objective of the article is to forecast the depths for one revolution and the mechanical drilling speed taking into account the decrease in the actual axial load due to the action of the frictional force.

Methods for conducting research. The analytical model of the vertical and horizontal displacements of the indenter along the surface of the rock has been improved. It is detailed with reference to drilling of boreholes by crowns of cutting type taking into account a decrease in the actual axial load acting on the cutter, for rocks with different physical and mechanical properties
Presentation of the main research. Let us analyze the model of interaction between the cutting tool of the rock-breaking tool and the rock, proposed by V.S. Vladislavlev and improved in work [13]. The idea being, that an imbedded cutter in the course of its movement along the well face is continuously leaving the sector compressed with the longitudinal load (impossible for further penetration). While displacing the opposing wall of the groove, the cutter comes over to the neighboring sector, not deformed and compressed yet. For that reason the cutter is gaining more penetration on the new sector under the same load. The process is illustrated in Fig. 1.

From position I, where it was in an h deep groove, the indenter along the $a-b$ line comes to position II. Thereafter it plunges by the value $h$, which corresponds to the longitudinal load $Q$ and resistance $Q_{r}$ of the compressed layer 2 of the rock.

In position I, a flat indenter 1 with a width of $\delta$ is embedded in the plastic rock to a depth $h$.

Then, along the $a-b$ line, it moves to position II, after which it sinks to a depth $h$ corresponding to the equilibrium of the vertical load $Q$ and the resistance force $Q_{r}$ of the compressed rock layer 2 .

After that, under the action of the circumferential force $P$, the indenter shifts the rock layer $2 h$ in thickness in front of it, moves a distance $\delta$ to position III along the $a_{1}-b_{1}$ line and is inserted by the same value $h$. The total depth of the indenter penetration reaches $3 h$.

When the indenter moves toward zero $(\delta \rightarrow 0)$, the implant will also tend to zero $(h \rightarrow 0)$. As a result, instead of a stepped trajectory, the movement of the indenter in a straight line will be obtained, the angle of inclination $\alpha$ to the plane perpendicular to the axis of the well is characterized by the tangent

$$
\operatorname{tg} \alpha=\frac{h}{\delta}
$$

Because of rotation the cutter's inclined direct line trajectory turns into a helix. In Fig. 2 an unfolding of its two first revolutions is shown.

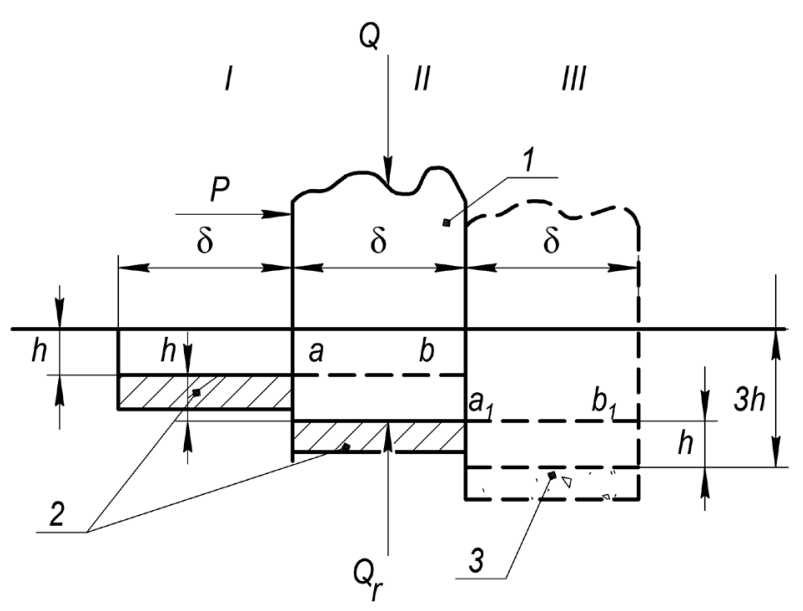

Fig. 1. A model of the indenter's penetrating, while moving along the well face (V. Vladislavlev) 


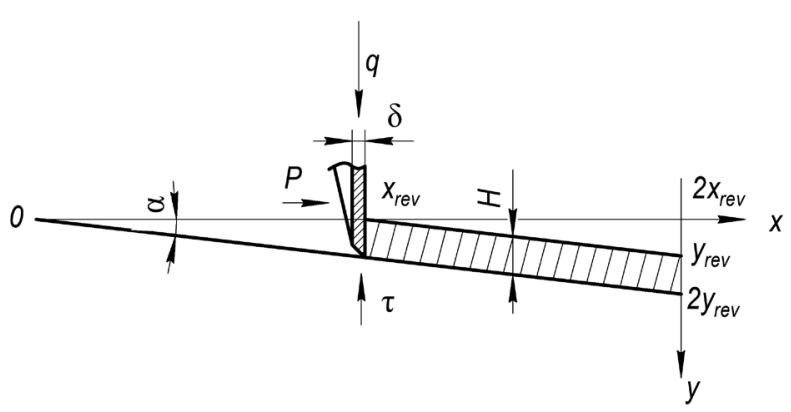

Fig. 2. The single isolated cutter's performance on the well face: unfolding - with two revolutions have been made (V. Vladislavlev):

$x$ - abscissa; $y$-ordinate; xrev - the length of revolution; $y_{\text {rev }}=H$ - penetration for revolution; $\alpha-$ the cutting line inclination to the well face; $\delta$ - the cutter width; $q$ - longitudinal load; $P$ - transverse load; $\tau$ - friction force

At the part of the unfolding, related to the first revolution, the penetration $y$ of the cutter and the thickness of the layer, removed by it, increases with the course along $x$. After having made the first revolution with $x=x_{\text {rev }}$ and gaining $y=H$ penetration, the cutter returns to its initial position (although at a greater depth). Henceforward in the course of the second and all the further revolutions the thickness of the layer preserves the constant value $H$. form

Hence expression (1) can be written in the following

$$
\operatorname{tg} \alpha=\frac{y_{\text {rev }}}{x_{\text {rev }}} .
$$

In Fig. 3 an unfolding of one revolution of a core bit, supplied with 3 cutters is shown. Fig. 3, $a$ shows the cutters in their initial position; various hatching being provided to the layers of rock, removed by various cutters.

Cutter No. 1, after having performed $1 / 3$ of revolution (from its initial position) runs into an $H$ tall wall, left by cutter No. 2. The same will occur with cutter No. 2: it will run into an $H$ tall wall, left by cutter No. 3 and that one, in turn, - in an $H$ tall wall, left by cutter No. 1 . Thus, after $1 / 3$ of revolution all 3 cutters (and the bit) will penetrate by the depth $H=y_{\text {rev }} / 3$ (Fig. 3, $b$, position I).

In Fig. $3, b$ in positions II and III shown are the cutters, completing $2 / 3$ and full revolution. After completing the full revolution all the cutters and the whole of the drill stem will penetrate by $y_{\text {rev }}=3 H$.

Thus, the layer of rock $y_{\text {rev }}$ that is removed per rotation is divided by the number of incisors

$$
H=\frac{y_{\text {rev }}}{m},
$$

where $m$ is the number of cutters, pcs.

The number of cutters does not influence the penetration per revolution. A single cutter with the same load, after having made one revolution, penetrates by some depth $y_{\text {rev }}$, as $m$ cutters

$$
q=\frac{Q}{m},
$$

where $Q$ is a bit load, $\mathrm{N}$.
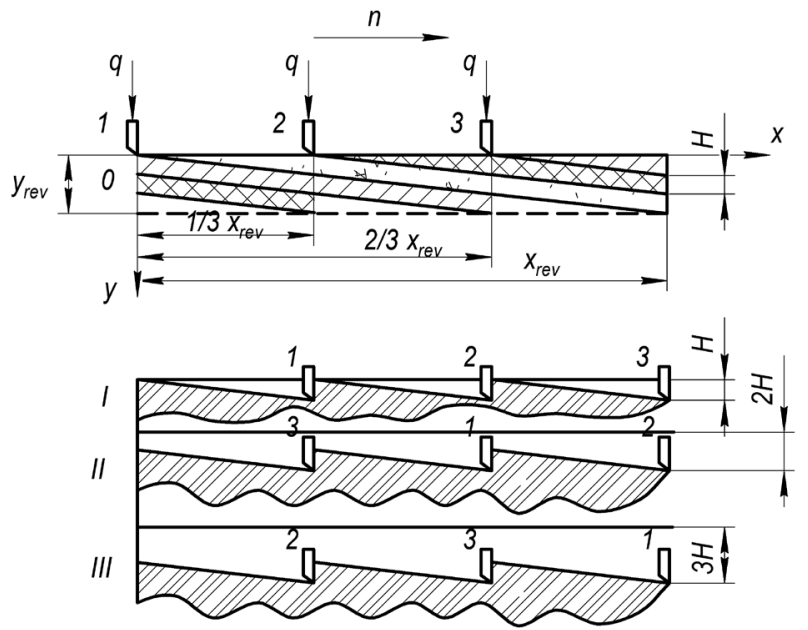

Fig. 3. Performance of the core bit, supplied with 3 cutters:

$a$ - the layers of the rock, removed with the cutters; $b-p o$ sitions I, II, III of the cutters after layer depth H tuple penetration; $x_{r e v}$ - the length of one revolution; $y_{\text {rev }}$ - the penetration per revolution; $n$ - rotation direction; $q$ - the cutter load

According to V. Vladislavlev

$$
\operatorname{tg} \alpha=\frac{2 q_{i}}{a \delta},
$$

where $\delta$ is dimension of the indenter along the line of its movement (Fig. 1), m; $q_{i}$ is intensity of the vertical load, $N / m ; a$ is rigidity of the indenter-rock couple, Pa.

Since the rigidity of the indenter is an order of magnitude higher than the rigidity of the rock, the indenter can be considered as an absolutely solid body, and then the rigidity of the pair will be determined only by the rigidity of the rock. In turn, the rigidity of the rock can be defined as

$$
a=\frac{E}{1-\mu^{2}},
$$

where $E$ is Young's modulus of the rock, $\mathrm{Pa} ; \mu$ is its Poisson's constant.

With reference to the conditions of the drilled well

$$
q_{i}=\frac{Q}{m b}
$$

where $b$ is the width of the well face along its radius, $m$.

Equating the value of $\operatorname{tg} \alpha$ obtained in formulas (2, $3)$, substituting $(4,5)$ in $(3)$ and taking into account the constrained working conditions of the cutters in the borehole, we obtain the expression for determining the recess in one revolution of the RCT

$$
y_{r e v}=x_{r e v} \frac{2 Q\left(1-\mu^{2}\right)}{b m E \delta \lambda},
$$

where $x_{r e v}$ is the length of a circumference, related to the cutter's middle; $\lambda$ is the coefficient, allowing for the constrained conditions of the cutters' work on the well face. According to V. Vladislavlev, $\lambda=1.38$. 
The drilling penetration speed is

$$
V_{m}=x_{r e v} \frac{2 Q\left(1-\mu^{2}\right)}{b m E \delta \lambda} n
$$

Table 1 presents an example of the above theory application for conditions of drilling limestone. For that rock $E=50000 \mathrm{MPa}, \mu=0.3$. The drilling is performed with a core bit with a diameter of $112 \mathrm{~mm}$, with four $(m=4)$ cutters with a transverse dimension of $b=9 \mathrm{~mm}$. The average length of the crown circumference is $x_{\text {rev }}=326 \mathrm{~mm}$. Axial bit load $Q=10000 \mathrm{~N}$, rotational frequency $n=100 \mathrm{rpm}$. We assume that during the drilling process, the tool does not blunt; its width $\delta$ remains constant (which is typical, for example, when drilling with self-sharpening crowns).

Obtained by formulas $(6,7)$, the results of the calculation of the penetration per revolution $y_{\text {rev }}$ and the drilling speed $V_{m}$, depending on the width of the tool $\delta$, are shown in Table 1.

According to V. Vladislavlev, while moving along the well face, the cutter, meeting the rock resistance, acts with its front facet on the wall of the groove with the force

$$
P=\sigma_{s h} \cdot F,
$$

where $\sigma_{s h}$ is breaking strength of the rock at shearing, $\mathrm{Pa} ; F$ is the area of the groove's front wall, $\mathrm{m}^{2}$

In turn

$$
F=b \cdot y_{\text {rev }} \text {. }
$$

On the front face of the cutter, the force $P$ brings friction force that will act in the plane of the front face of the cutter. It is directed upwards from the cutting edge in contact with the rock, since the friction force is directed in the opposite direction of motion, and the cutting edge goes deeper into the rock.

$$
\tau=P f
$$

where $f$ is a friction coefficient.

The vertical load $Q$ and the friction force $\tau$ are two differently directed forces, and according to the rule of addition of forces, the net force will be equal to the algebraic sum of these forces. Thus the actual value of the bit load

$$
Q_{a}=Q-\tau \text {. }
$$
force

Substituting $(8,9)$ into $(10)$ we define the friction

\section{Table 1}

The dependency of penetration per revolution and penetration speed on the cutter's blunting area width

\begin{tabular}{|l|c|c|c|c|c|c|c|}
\hline $\begin{array}{c}\text { Width of } \\
\text { cutter } \delta, \mathrm{mm}\end{array}$ & 2 & 1.5 & 1 & 0.8 & 0.6 & 0.4 & 0.2 \\
\hline $\begin{array}{l}\text { Penetration } \\
\text { per revolution } \\
y_{\text {rev }}, \mathrm{mm}\end{array}$ & 1.19 & 1.59 & 2.39 & 2.99 & 3.98 & 5.97 & 11.94 \\
\hline $\begin{array}{l}\text { Penetration } \\
\text { rate } V_{m}, \mathrm{~m} / \mathrm{h}\end{array}$ & 7.2 & 9.6 & 14.3 & 17.9 & 23.9 & 35.8 & 71.7 \\
\hline
\end{tabular}

$$
\tau=\sigma_{\text {sh }} b y_{\text {rev }} f .
$$

Substituting (12) into (11), we determine the true value of the axial load

$$
Q_{a}=Q-\sigma_{s h} b y_{\text {ren }} f \text {. }
$$

From (13) we find the value of the recess in one revolution

$$
y_{\text {rev }}=\frac{Q-Q_{a}}{\sigma_{s h} b f} .
$$

Substituting in the formula (6) the true value of the axial load at the RCT load and equating $(13,14)$, we obtain an expression that will allow us to find the true value of the axial load

$$
x_{\text {rev }} \frac{2 Q_{a}\left(1-\mu^{2}\right)}{b m E \delta \lambda}=\frac{Q-Q_{a}}{\sigma_{s h} b f} .
$$

Let us express the true value of the axial load

$$
Q_{a}=\frac{Q}{\sigma_{s h} f \cdot\left(\frac{2 x_{r e v}\left(1-\mu^{2}\right)}{m E \delta \lambda}+\frac{1}{\sigma_{s h} f}\right)} .
$$

After the transformations, we finally obtain

$$
Q_{a}=\frac{Q m E \delta \lambda}{2 x_{r e v} \sigma_{s h} f\left(1-\mu^{2}\right)+m E \delta \lambda} .
$$

We determine the values of the true axial load for the same conditions that were adopted in the calculation of these values earlier. In addition, the following values were accepted: the hard alloy-rock friction coefficient $f=0.55$ (some characteristic values of the coefficient of friction for various rocks and cutter material are given in [14]); Limestone's shear strength, measured in the laboratory conditions is $12 \mathrm{MPa}$, but taking into account the geostatic and hydrostatic pressures occurring in the well conditions, the coefficient 4 is applied to this value, the value is $48 \mathrm{MPa}$.

In addition, we find the values of the recess in one revolution and the drilling speed from formulas $(14,7)$, substituting the value of the true axial load obtained by formula (15) in them.

The results of calculations are summarized in Table 2. Also Table 2 shows the values of the calculation of the horizontal force $P$ and the frictional force $\tau$ calculated by formulas $(8,10)$.

Fig. 4 shows the results of a comparative analysis in calculating the mechanical drilling speed with and without friction forces.

Comparison of Tables 1, 2 enables us to make a conclusion, that the sharper the cutter is, the greater reduction in its penetration rate is, caused by reduction of the bit load brought about by friction forces. So if for the cutters with blunting of $2 \mathrm{~mm}$ the penetration rate drops for that reason by only $2.8 \%$ (from 7.20 to $7.0 \mathrm{~m} / \mathrm{h}$ ), for the cutters with $\delta=0.2 \mathrm{~mm}$ that drop attains as much as $22.1 \%$ (from 71.7 to $55.8 \mathrm{~m} / \mathrm{h}$ )

It is possible to ascertain that due to proportional dependency (7), the drop in penetration is caused by the same relative drop of the bit load. 
The dependency of the actual bit load, penetration per revolution and penetration speed on the cutter's blunting area width with consideration of friction forces

\begin{tabular}{|l|c|c|c|c|c|c|c|}
\hline \multicolumn{1}{|c|}{ Width of cutter $\delta, \mathrm{mm}$} & 2 & 1.5 & 1 & 0.8 & 0.6 & 0.4 & 0.2 \\
\hline Actual bit load $Q, \mathrm{~N}$ & 9724 & 9635 & 9463 & 9338 & 9136 & 8757 & 7790 \\
\hline Penetration per revolution $y_{\text {rev }}, \mathrm{mm}$ & 1.16 & 1.53 & 2.26 & 2.79 & 3.64 & 5.23 & 9.30 \\
\hline Horizontal force $P, \mathrm{H}$ & 502 & 663 & 976 & 1204 & 1571 & 2259 & 4019 \\
\hline Friction force $\tau, \mathrm{H}$ & 276 & 365 & 537 & 662 & 864 & 1243 & 2210 \\
\hline Penetration rate $V_{m}, \mathrm{~m} / \mathrm{h}$ & 7.0 & 9.2 & 13.6 & 16.7 & 21.8 & 31.4 & 55.8 \\
\hline
\end{tabular}

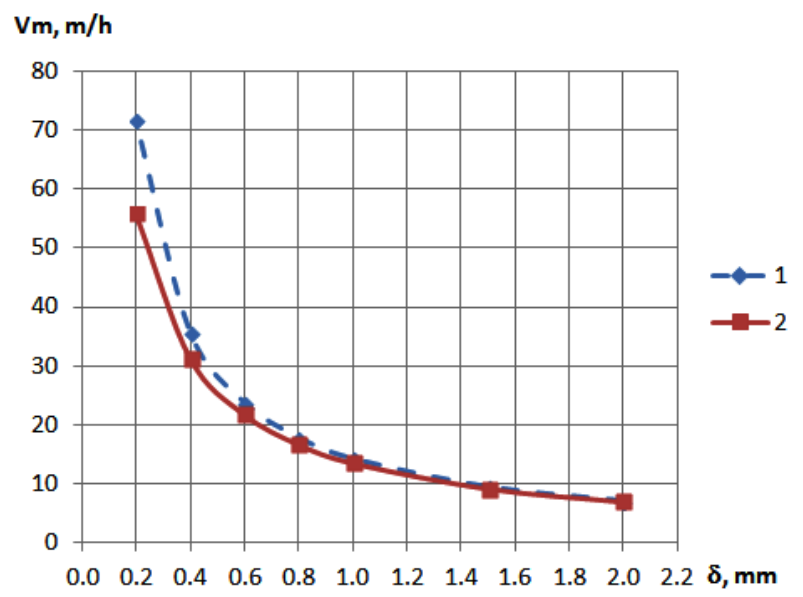

Fig. 4. Dependence of the mechanical drilling speed on the cutter width:

1 - calculated dependence without allowance for frictional forces; 2 - calculated dependence with allowance for frictional forces

\section{Conclusions.}

1. The updating of the borehole drilling technology must be based upon an adequate theory of the drilled rock destruction.

2. Two theoretical models of drilling process are currently in use:

- a model, according to which the cutter's imbedding process is preceding the process of spreading the destruction zone all over the well face;

- a model, according to which both processes are proceeding at the same time.

3. The second model is adequate as applied to the cutting type drilling with the cutter removing from the well face a layer of rock.

4. It is established that during the drilling, the true axial load is lower than the nominal load due to the frictional force arising on the front face of the tool.

5. The model predicted protracted operations associated with operations.

6. It is revealed that with a decrease in the width of the cutting (i.e., its aggravation), the axial load losses increase.

\section{References.}

1. Kozhevnykov, A. A., Ratov, B. T., Arshidinova, M. T., Khomenko, V.L., Bayboz, A. R. and Sabirov, B. F., 2017. The $100^{\text {th }}$ Anniversary of the Establishment of the Carbide: Carbide Bit. International Journal of Chemical Sciences, 15(2), p. 188.
2. Ratov, B. T., Khomenko, V. L., Bayboz, A. R. and Delikesheva, D. N., 2017. Classification of the drilling hardalloy tool. Mining journal of Kazakhstan, 11, pp. 31-38. 3. Neskoromnykh, V.V. and Popova, M. S., 2018. Principles of system approach to designing drilling tools. Construction of oil and gas wells on land and sea, 8, pp. 26-31.

4. Neskoromnyh, V. V., 2015. Analysis of the process of destruction of anisotropic rock by roller cone bits. Bulletin of the Tomsk Polytechnic University, 326(2), pp. 80-89. 5. Pialchenkov, V.A., 2015. Analytical study of the deformability of roller cone bits. Modern problems of science and education [pdf], 1. Available at: <www.science-education.ru/pdf/2015/1/595.pdf> [Accessed 6 November 2017].

6. Sinev, S. V., 2016. Mechanisms, methods and ways of destruction of rocks in roller-hole drilling. Mining information-analytical bulletin, 1, pp. 149-159.

7. Dolgy, I. Ye. and Nikolayev, N. I., 2016. Resistance of rocks to fracture during drilling of wells. Notes of the Mining Institute, 221, pp. 655-660. DOI: 10.18454/ PMI.2016.5.655.

8. Bilgin, N., Copur, H. and Balci, C., 2013. Mechanical excavation in mining and civil industries. BocaRaton, London, New York: CRC Press.

9. Litvinsky, G. G., 2017. Fundamentals of the theory of cutting and fracture of rocks. Collection of scientific papers DSTU, 8(51), pp. 5-15.

10. Tretyak, A.A., Grossu, A. N. and Borisov, K.A., 2015. Constructions of drill bits reinforced with PDC, taking into account the destruction scheme of the bottomhole. Construction of oil and gas wells on land and at sea, 6, pp. 9-12.

11. Sysoyev, N. I., Burenkov, N. N. and Hung, Ch. K., 2016. Justification of the structure and choice of rational design parameters of the drill cutter reinforced with diamond-hard alloy plates. North-Caucasian region. Technical science, 2(190), pp. 77-83. DOI: 10.17213/03212653-2016-2-77-83.

12. Zaitsev, V. I., Karpikov, A. V. and Che, V.V., 2014. Efficiency of using PDS bits. Siberian Branch of the Earth Sciences Section of the Russian Academy of Natural Sciences. Geology, exploration and development of mineral deposits, 5(48), pp. 58-66.

13. Biletsky, M.T., Ratov, B.T., Kozhevnykov, A.A., Baiboz, A. R. and Delikesheva, D. N., 2018. Updating the theoretic model of rock destruction in the course of drilling. News of the National Academy of Sciences of the 
Republic of Kazakhstan. Series of geology and technical sciences, 2, pp. 63-71.

14. Zhabin, A.B., Poliakov, A.V., Averin, E.A. and Sarychev, V.I., 2018. The state of scientific research in the field of rock destruction by the incisive tool at the turn of the century. Tula State University. Earth sciences, 1, pp. 230-247.

\section{Залежність швидкості буріння від сил тертя на різцях породоруйнуючого інструмента}

\author{
М. Т. Білецький ${ }^{1}$, А. О. Кожевников ${ }^{2}$, Б. Т. Ратов $^{1}$, \\ В. Л. Хоменко ${ }^{2}$
}

1 - Каспійський громадський університет, м. Алмати, Республіка Казахстан, e-mail: biletskymarc@yandex.ru; ratov69@mail.ru

2 - Національний технічний університет „Дніпровська політехніка“, м. Дніпро, Україна, e-mail: aak2@ua.fm; inteldriller@gmail.com

Мета. Прогнозування поглиблення за один оберт і механічної швидкості буріння з урахуванням зниження справжнього осьового навантаження через дію вертикальної сили тертя.

Методика. Удосконалена аналітична модель поєднаного у часі вертикального й горизонтального руху індентора по поверхні гірської породи. Вона деталізована по відношенню до буріння свердловин коронками ріжучого типу з урахуванням зменшення справжнього осьового навантаження, що діє на різець, по породам з різними фізико-механічними властивостями.

Результати. Установлено, що у процесі буріння справжнє осьове навантаження менше, ніж номінальне за рахунок дії сили тертя, що виникає на передній грані різця. Прогнозовані поглиблення за один оберт і механічна швидкість буріння з урахуванням зниження справжнього осьового навантаження внаслідок дії вертикальної сили тертя. Виявлено, що зі зменшенням ширини різця збільшуються втрати осьового навантаження через дію сили тертя, а поглиблення за один оберт і швидкість буріння зменшуються більш інтенсивно.

Наукова новизна. Уперше показано вплив сили тертя, що виникає на передній грані різця породоруйнуючого інструменту, на справжнє осьове навантаження, поглиблення за один оберт і механічну швидкість буріння. Запропоновані нові аналітичні залежності, що дозволяють прогнозувати поглиблення за один оберт і механічну швидкість буріння.

Практична значимість. Розроблена модель взаємодії різця породоруйнуючого інструменту з породою дозволить більш достовірно прогнозувати результати використання різних конструкцій і технологій відпрацювання породоруйнуючого інструменту, а також обирати раціональні технології їх використання для досягнення максимальних техніко-економічних показників.

Ключові слова: буріння свердловин, руйнування гірських порід, породоруйнуючий інструмент, твердосплавна коронка, поглиблення за один оберт, механічна швидкість буріння

\section{Зависимость скорости бурения от сил трения на резцах породоразрушающего инструмента}

\author{
М. Т. Билеикий', А. А. Кожевников ${ }^{2}$, Б. Т. Ратов ${ }^{1}$, \\ В. Л.Хоменко ${ }^{2}$
}

1 - Каспийский общественный университет, г. Алматы, Республика Казахстан, e-mail: biletskymarc@yandex.ru; ratov69@mail.ru

2 - Национальный технический университет „Днепровская политехника“, г. Днепр, Украина, e-mail: aak2@ua. fm; inteldriller@gmail.com

Цель. Прогнозирование углубки за один оборот и механической скорости бурения с учетом снижения истинной осевой нагрузки вследствие действия вертикальной силы трения.

Методика. Усовершенствована аналитическая модель совмещенного во времени вертикального и горизонтального перемещений индентора по поверхности горной породы. Она детализирована применительно к бурению скважин коронками режущего типа с учетом уменьшения истинной осевой нагрузки, действующей на резец, по породам с различными физико-механическими свойствами.

Результаты. Установлено, что в процессе бурения истинная осевая нагрузка меньше, чем номинальная за счет действия силы трения, возникающей на передней грани резца. Спрогнозированы углубка за один оборот и механическая скорость бурения с учетом снижения истинной осевой нагрузки вследствие действия вертикальной силы трения. Выявлено, что с уменьшением ширины резца увеличиваются потери осевой нагрузки вследствие действия силы трения, а углубка за один оборот и скорость бурения снижаются более интенсивно.

Научная новизна. Впервые показано влияние силы трения, возникающей на передней грани резца породоразрушающего инструмента, на истинную осевую нагрузку, углубку за один оборот и механическую скорость бурения. Предложены новые аналитические зависимости, позволяющие прогнозировать углубку за один оборот и механическую скорость бурения.

Практическая значимость. Разработанная модель взаимодействия резца породоразрушающего инструмента с породой забоя позволит более достоверно прогнозировать результаты применения различных конструкций и технологий отработки породоразушающего инструмента, а также выбирать рациональные технологии их применения для достижения максимальных технико-экономических показателей.

Ключевые слова: бурение скважин, разрушение горных пород, породоразрушающий инструмент, твердосплавная коронка, углубка за один оборот, механическая скорость бурения

Рекомендовано до публікації докт. техн. наук О.М.Давиденком. Дата надходження рукопису 02.10 .17 . 